\title{
Optimasi dan validasi metode analisis residu klorpirifos menggunakan High Performance Liquid Chromatography (HPLC)
}

\author{
Abdon Saiya*, Dokri Gumolung, Dian Herlinda Octorina Howan
}

Kimia FMIPA, Universitas Negeri Manado, Tondano, 95619, Indonesia

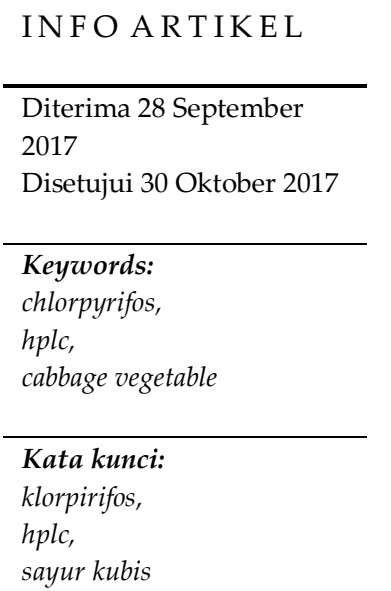

${ }^{*}$ e-mail:

abdonsaiya@unima.ac.id

${ }^{*}$ Telp:

085240868530

\begin{abstract}
A B STRACT
One of the most sensitive and selective instrumentation techniques for the analysis of pesticide residues in vegetables at a high level is High Performance Liquid Chromatography (HPLC). To obtain optimum result of measurement, optimization and validation of measurement method is needed. The purpose of this research is to optimize and validate the determination of chlorpyrifos concentration by HPLC method, so it can be used for analysis of chlorpyrifos residues in samples of cabbage vegetables taken from some traditional markets in North Sulawesi. Optimized chromatographic parameters are the composition of mobile phase of water and acetonitrile, mobile phase flow rate, and the volume of the sample injection. While the validated measurement parameters include precision, linearity, detection limits, and quantitation limits. Based on the results obtained using Zorbax Eclipse Plus C18 column, the optimum condition of HPLC was achieved at $\lambda_{\max }$ of $289 \mathrm{~nm}$, mobile phase composition of water: acetonitrile was 10:90, mobile phase flow rate of $0.70 \mathrm{~mL} / \mathrm{min}$, and sample injection volume of $15 \mu \mathrm{L}$. The result of validation of analytical method shows that analytic performance of determination of chlorpyrifos with HPLC method is very good, it is indicated by measurement parameter such as precision shown with coefficient of variation $(\mathrm{CV})$ was $0,2086 \%$, linearity indicated by correlation coefficient $(r)$ was 0.9963 , the detection limit (LOD) of $0.67 \mathrm{ppm}$, and the quantitative limit (LOQ) of $2.24 \mathrm{ppm}$, which all meet the requirements. The results of this study indicate that this method can be used for analysis of chlorpyrifos residues in cabbage vegetable samples.
\end{abstract}

\section{A B STRAK}

Salah satu teknik instrumentasi yang sensitif dan selektif untuk analisis residu pestisida dalam sayur-sayuran pada level renik adalah High Performance Liquid Chromatography (HPLC). Untuk memperoleh hasil pengukuran yang optimum, perlu dilakukan optimasi dan validasi metode pengukuran tersebut. Tujuan penelitian ini adalah melakukan optimasi dan validasi penentuan konsentrasi klorpirifos dengan metode HPLC, sehingga dapat digunakan untuk analisis residu klorpirifos dalam sampel sayur kubis yang diambil dari beberapa pasar tradisional di Sulawesi Utara. Parameter kromatografik yang dioptimasi adalah komposisi fasa gerak air dan asetonitril, laju alir fasa gerak, dan volume injeksi sampel. Sedangkan parameter pengukuran yang divalidasi meliputi presisi, linearitas, batas deteksi, dan batas kuantitasi. Berdasarkan hasil penelitian yang diperoleh menggunakan kolom Zorbax Eclipse Plus C18, kondisi optimum HPLC dicapai pada $\lambda_{\text {maks }}=289 \mathrm{~nm}$, komposisi fasa gerak air : asetonitril (10:90), laju alir fasa gerak $0,70 \mathrm{~mL} / \mathrm{menit}$, dan volume injeksi sampel $15 \mu \mathrm{L}$. Hasil validasi metode anlisis tersebut menunjukkan bahwa kinerja analitik penentuan klorpirifos dengan metode HPLC tergolong sangat baik, hal ini ditunjukkan dengan parameter pengukuran seperti presisi yang ditunjukkan dengan koefisien variasi (KV) sebesar 0,2086\%, linearitas yang ditunjukkan dengan koefisien korelasi (r) sebesar 0,9963, batas deteksi (LOD) sebesar 0,67 ppm, dan batas kuantitasi (LOQ) sebesar 2,24 ppm, yang semuanya memenuhi persyaratan. Hasil penelitian ini menunjukkan bahwa metode ini dapat digunakan untuk analisis residu klorpirifos dalam sampel sayur kubis. 


\section{Pendahuluan}

Pestisida merupakan salah satu bahan kimia yang banyak digunakan di bidang pertanian sebagai pengendali hama tanaman dan merupakan salah satu aspek penentu keberhasilan produksi pertanian tersebut. Namun demikian, penggunaan pestisida yang berlebihan dan tidak terkendali dapat menyebabkan tertinggalnya residu pestisida pada berbagai hasil pertanian maupun lingkungan. Demikian juga perilaku petani dalam penggunaan pestisida kemungkinan besar mempengaruhi besarnya residu pestisida dalam komoditi pertanian sehingga perlu dikaji sejauh mana residu pestisida yang terakumulasi pada hasil-hasil pertanian karena pemakaian pestisida.

Salah satu jenis pestisida yang banyak digunakan oleh petani adalah pestisida golongan organofosfat dengan bahan aktif klorpirifos. Hal ini disebabkan karena pestisida organofosfat memiliki karakteristik yang lebih menguntungkan dibandingkan dengan pestisida organoklorin, seperti mudah terurai dan waktu persistennya yang singkat [1]. Pestisida organofosfat melindungi tanaman dari hama dengan menghambat aktivitas enzim asetilkolineterase pada serangga. Penggunaannya dengan cara disemprot pada tanaman atau tanah, menyebabkan residunya dapat ditemukan di permukaan air tanah, buahbuahan, sayuran dan air minum [2]. Klorpirifos (o,o-dietil-o-3,5,6 trichloropyridin-2-ilphosphorothioate) merupakan kristal organofosfat insektisida yang cukup beracun dan paparan kronis dapat menyebabkan efek neurologis, gangguan pertumbuhan, dan gangguan autoimun. Klorpirifos memiliki keuntungan lebih dari produk lainnya yaitu efektif terhadap berbagai hama serangga pemakan tanaman [3].

Karena kadar residu klorpirifos yang terdapat dalam sampel hasil-hasil pertanian biasanya sangat rendah, maka diperlukan metode analisis yang sensitif dan selektif yang dapat mendeteksi senyawa klorpirifos dan dapat digunakan secara rutin dan berbiaya murah. Salah satu teknik instrumentasi yang sensitif dan selektif untuk analisis senyawa organik dalam level renik adalah High Performance Liquid Chromatography (HPLC) [4].
Berdasarkan kajian literatur diperoleh informasi bahwa penelitian tentang optimasi dan validasi metode analisis untuk penentuan klorpirifos menggunakan HPLC telah dilaporkan oleh Panggabean [5]. Dalam penelitiannya tentang analisis residu klorpirifos dalam sayur-sayuran dengan teknik HPLC, telah dilakukan optimasi dan penentuan kinerja analitik beberapa parameter kromatografik menggunakan fasa gerak air dan metanol. Hasil penelitian tersebut menunjukkan bahwa teknik HPLC dapat digunakan untuk menentukan residu klorpirifos dalam sayur-sayuran dengan ketelitian dan keakuratan yang tinggi. Namun pada penelitian tersebut belum dicoba kombinasi fasa gerak air dan asetonitril, padahal diketahui klorpirifos merupakan senyawa yang cukup baik kelarutannya dalam asetonitril.

Pada penelitian ini telah dilakukan optimasi dan validasi metode analisis untuk penentuan klorpirifos dengan HPLC menggunakan fasa gerak air dan asetonitril untuk beberapa parameter kromatografik, di antaranya komposisi fasa gerak, laju alir fasa gerak, volume injeksi sampel, presisi, linearitas, batas deteksi, dan batas kuantitasi. Setelah metode analisis tersebut dioptimasi dan divalidasi, diharapkan dapat diaplikasikan untuk menentukan kadar residu klorpirifos dalam sampel sayur kubis.

\section{Bahan dan Metode}

Peralatan yang digunakan dalam penelitian ini antara lain: seperangkat alat HPLC (Agilent 1260 Infinity Binary LC) yang dilengkapi dengan detektor DAD, utosampler, dan kolom Zorbax Eclipse Plus C18 (3,5 m; 2,1 x 100 mm), Spektrofotometer UV-Vis PerkinElmer Lambda 25, rotavapor, sonikator, neraca analitik, penyaring vakum beserta saringan berpori 0,4 $0,45 \mu \mathrm{m}$, blender, corong pisah dengan tutup, penangas air, pompa vakum, dan alat gelas yang lazim.

Sedangkan bahan yang digunakan antara lain Zat standar klorpirifos (kemurnian $\geq 99,9 \%$, Merck), Asetonitril (gradient grade, $\geq 99,9 \%$, Merck), etilasetat, $\mathrm{Na}_{2} \mathrm{SO}_{4}$ anhidrat, aquabidest.

Secara garis besar, prosedur penelitian ini dibagi menjadi beberapa tahap, yaitu: 
1. Penentuan panjang gelombang serapan maksimum klorpirifos

Panjang gelombang serapan maksimum klorpirifos ditentukan dengan mengukur serapan larutan baku klorpirifos 10 ppm menggunakan spektrofotometer UV/Vis Lambda 25.

\section{Penentuan kondisi optimum HPLC}

Kondisi optimum HPLC ditentukan menggunakan kolom Zorbax Eclipse Plus C18 (3,5 $\mu \mathrm{m} ; 2,1 \times 100 \mathrm{~mm})$ menggunakan detektor DAD pada panjang gelombang $289 \mathrm{~nm}$. Penentuan kondisi optimum HPLC meliputi:

a. Penentuan Komposisi Fasa Gerak

Fasa gerak yang digunakan dalam penelitian ini adalah air dan asetonitril dengan komposisi air : asetonitril divariasikan dari 100:0; 90:10; 80:20; 70:30; 60:40; 50:50; 40:60; 30:70; 20:80, 10:90, dan 0:100. Sebanyak $5 \mu \mathrm{L}$ larutan baku klorpirifos 2 ppm diinjeksikan ke dalam kolom HPLC kemudian ditentukan waktu retensi dan luas area puncak kromatogram masing-masing komposisi fasa gerak tersebut.

\section{b. Penentuan Laju Alir Fasa Gerak}

Laju alir fasa gerak dipalajari dengan mengukur waktu retensi dan luas area puncak kromatogram larutan baku klorpirifos 2 ppm pada laju alir yang divariasikan dari 0,3 - 0,9 $\mathrm{mL} /$ menit menggunakan komposisi fasa gerak optimum yang telah ditentukan sebelumnya.

\section{c. Penentuan Volume Injeksi}

Volume injeksi sampel dipelajari dengan mengukur luas area puncak kromatogram larutan baku klorpirifos 2 ppm dengan volume injeksi divariasikan dari 5-30 $\mu \mathrm{L}$ menggunakan komposisi dan laju alir fasa gerak optimum yang telah ditentukan sebelumnya.

\section{Penentuan Kinerja Analitik}

Setelah ditentukan kondisi optimum HPLC, selanjutnya ditentukan kinerja analitik yang meliputi:

\section{a. Presisi}

Presisi ditetapkan berdasarkan keterulangan (repeatability) yang ditentukan dengan mengukur luas area puncak kromatogram larutan baku klorpirifos 2 ppm pada kondisi optimum HPLC. Pengukuran diulangi sebanyak 7 kali kemudian ditentukan simpangan baku relatif (SBR) atau keoefisien variasi $(\mathrm{KV})$.

\section{b. Linearitas dan Kurva kalibrasi}

Kurva kalibrasi dibuat dengan mengukur luas area puncak kromatogram larutan baku klorpirifos dengan konsentrasi yang divariasikan dari 0 - 10 ppm menggunakan kondisi optimum HPLC yang telah ditentukan sebelumnya. Kemudian dibuat kurva kalibrasi dengan mengalurkan luas area puncak kromatogram (sebagai sumbu-y) terhadap konsentrasi larutan baku klorpirifos (sebagai sumbu-x), lalu dihitung persamaan garis regresi dan koefisien korelasinya.

\section{c. Batas Deteksi dan Batas Kuntitasi}

Dalam penelitian ini, nilai batas deteksi (LOD) dan batas kuantitasi (LOQ) dihitung secara statistik melalui garis regresi dari kurva kalibrasi [6]. Nilai LOD dihitung menggunakan persamaan:

$$
L O D=\frac{3 S_{(y / x)}}{b}
$$

Sedangkan nilai LOQ dihitung menggunakan persamaan:

$$
L O Q=\frac{10 S_{(y / x)}}{b}
$$

Dimana $S_{(y / x)}$ adalah simpangan baku residual, dan $b$ adalah slope dari persamaan garis regresi linier.

\section{Hasil dan Pembahasan}

1. Panjang Gelombang Serapan Maksimum Klorpirifos

Panjang gelombang serapan maksimum klorpirifos ditentukan dengan mengukur serapan larutan baku klorpirifos $10 \mathrm{mg} / \mathrm{L}$ menggunakan spektrofotometer UV/Vis Lambda 25 pada rentang panjang gelombang $190-700 \mathrm{~nm}$. Berdasarkan hasil pengukuran diperoleh tiga daerah serapan larutan baku klorpirifos, yaitu pada $\lambda=209 \mathrm{~nm}, \lambda=229 \mathrm{~nm}$, dan $\lambda=289 \mathrm{~nm}$, seperti diperlihatkan dalam Gambar 1a. Panjang gelombang serapan maksimum klorpirifos yang dipilih untuk digunakan dalam penelitian ini adalah $\lambda=289$ $\mathrm{nm}$, karena pada panjang gelombang tersebut 
tidak terjadi tumpang tindih, seperti diperlihatkan dalam Gambar 1b.

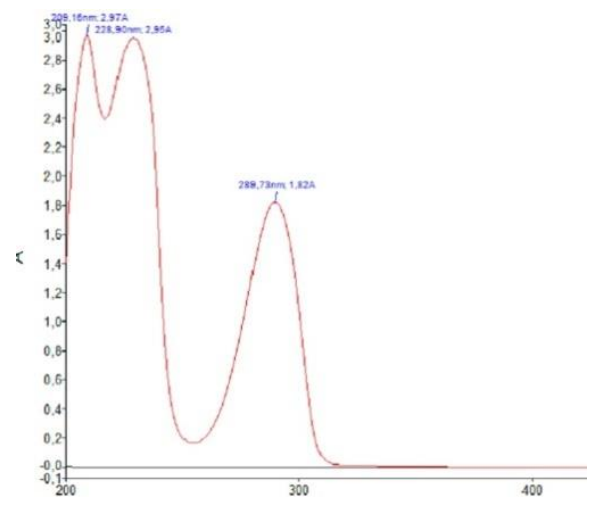

(a)

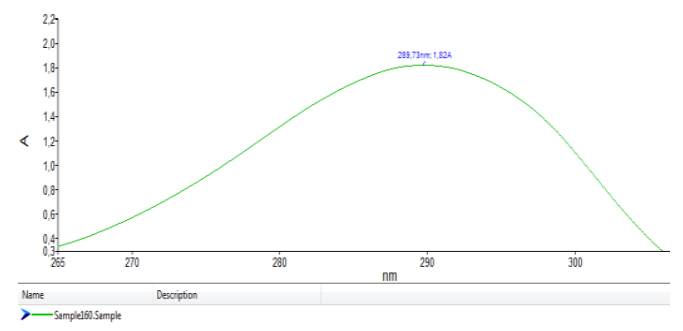

(b)

Gambar 1. (a) Panjang gelombang serapan klorpirifos, (b) Serapan klorpirifos pada $\lambda=289$ nm yang diperbesar

Panjang gelombang serapan maksimum klorpirifos tersebut selanjutnya digunakan untuk melakukan optimasi kondisi pengukuran HPLC menggunakan detektor DAD pada panjang gelombang tersebut.

\section{Kondisi Optimum HPLC}

a. Pengaruh Komposisi Fasa gerak

Fasa gerak yang digunakan dalam penelitian ini adalah air dan asetonitril yang bersifat lebih polar dibandingkan fasa diam, yakni C18 yang bersifat nonpolar. Komposisi fasa gerak optimum ditentukan berdasarkan luas area puncak kromatogram dan waktu retensi, karena luas puncak merupakan parameter yang lebih akurat untuk pengukuran kuantitatif [4].

Berdasarkan hasil pengukuran didapati bahwa kromatogram klorpirifos mulai terbaca pada komposisi air : asetonitril 50 : 50 seperti ditunjukkan dalam Gambar 2.

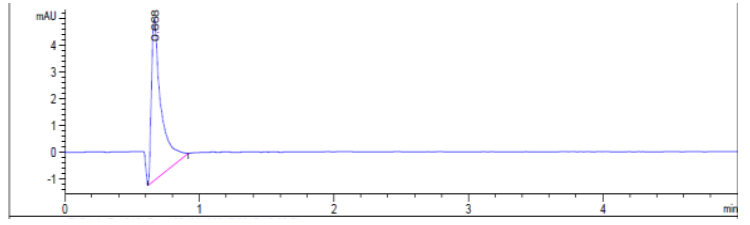

(a)

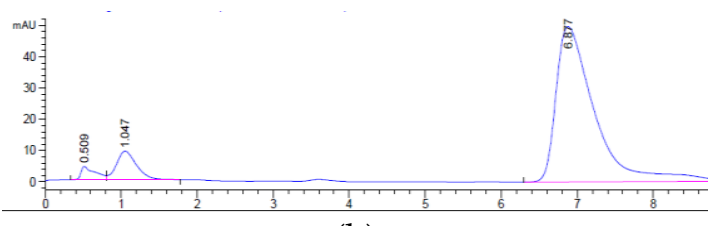

(b)

Gambar 2. Kromatogram blangko (a) dan kromatogram larutan baku klorpirifos 2 ppm

(b), pada komposisi air : asetonitril (50:50)

Hasil pengukuran selengkapnya pada berbagai komposisi fasa gerak air:asetonitril diperlihatkan dalam Tabel 1.

Tabel 1. Pengaruh komposisi air:asetonitril terhadap waktu retensi dan luas area

\begin{tabular}{ccc}
\hline $\begin{array}{c}\text { Komposisi } \\
\text { Air:Asetonitril }\end{array}$ & $\begin{array}{c}\text { Waktu } \\
\text { Retensi } \\
\text { (menit) }\end{array}$ & $\begin{array}{c}\text { Luas Area } \\
\text { (mAU*) }\end{array}$ \\
\hline $50: 50$ & 6,877 & 1753,36926 \\
$40: 60$ & 6,724 & 32,82681 \\
$30: 70$ & 3,055 & 32,73163 \\
$20: 80$ & 1,797 & 32,44448 \\
$10: 90$ & 1,184 & 32,23305 \\
$0: 100$ & 0,999 & 32,98140 \\
\hline
\end{tabular}

Berdasarkan data pada Tabel 1 dapat dilihat bahwa jika komposisi astonitril diperbesar, maka luas area puncak kromatogram klorpirifos semakin berkurang namun waktu retensinya semakin singkat. Luas area puncak kromatogram klorpirifos terbesar terbaca pada komposisi air:asetonitril (50:50), namun waktu retensinya lebih lama dan kromatogram yang dihasilkan tidak simetris. Oleh karena itu, komposisi fasa gerak air : asetonitril yang digunakan dalam penelitian ini adalah 10 : 90, karena waktu pengukurannya lebih singkat dan luas area puncak kromatogramnya masih cukup baik (Gambar 3). 


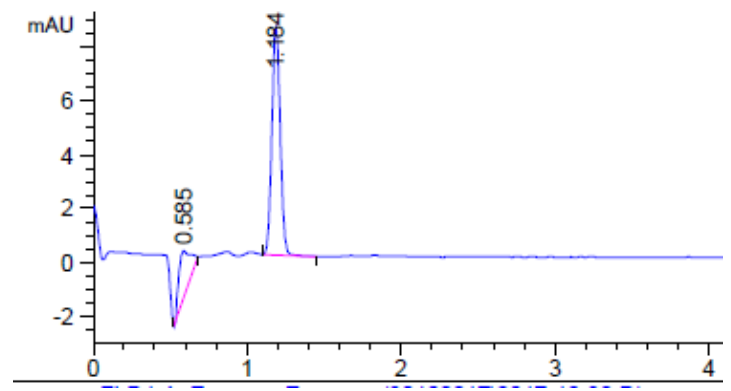

Gambar 3. Kromatogram lorpirifos pada komposisi fasa gerak air : asetonitril $(10: 90)$

\section{b. Pengaruh Laju Alir Fasa Gerak}

Pengukuran laju alir fasa gerak dilakukan menggunakan komposisi fasa gerak optimum yang telah ditentukan sebelumnya, yaitu pada perbandingan air : asetonitril $10: 90$. Hasil pengkuran tersebut ditunjukkan dalam Tabel 2 berikut.

Tabel 2. Pengaruh Laju Alir Fasa Gerak terhadap Waktu Retensi dan Luas Area

\begin{tabular}{ccc}
\hline $\begin{array}{c}\text { Laju Alir Fasa } \\
\text { Gerak } \\
\text { (mL/menit) }\end{array}$ & $\begin{array}{c}\text { Waktu } \\
\text { Retensi } \\
\text { (menit) }\end{array}$ & $\begin{array}{c}\text { Luas Area } \\
\text { (mAU*s) }\end{array}$ \\
\hline 0,30 & 1,682 & 162,69608 \\
0,50 & 1,006 & 97,39092 \\
0,70 & 0,720 & 72,81155 \\
0,90 & 0,561 & 61,86494 \\
\hline
\end{tabular}

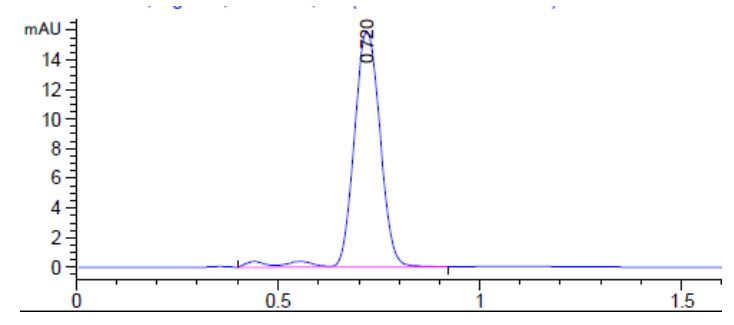

Gambar 4. Kromatogram klorpirifos pada laju alir fasa gerak $0,70 \mathrm{~mL} /$ menit

Berdasarkan data pada Tabel 2, dapat dilihat bahwa semakin tinggi laju alir fasa gerak, semakin singkat waktu retensi dan semakin kecil luas area puncak kromatogram yang dihasilkan. Kromatogram terbaik dengan waktu retensi lebih singkat diperoleh pada laju alir 0,70 $\mathrm{mL} / \mathrm{menit}$ (Gambar 4). Pada laju alir 0,90
$\mathrm{mL} /$ menit, kromatogram yang dihasilkan tidak simetris lagi.

c. Pengaruh Volume Injeksi Sampel

Pengukuran parameter volume injeksi sampel dilakukan menggunakan komposisi dan laju alir fasa gerak optimum yang telah ditentukan sebelumnya, yaitu komposisi air : asetonitril 10:90 dan laju alir 0,70 mL/menit. Hasil pengkuran tersebut ditunjukkan dalam Tabel 3 berikut.

Tabel 3. Pengaruh Volume Injeksi Sampel terhadap Waktu Retensi dan Luas Area

\begin{tabular}{ccc}
\hline $\begin{array}{c}\text { Volume } \\
\text { Injeksi } \\
\text { Sampel }(\boldsymbol{\mu L})\end{array}$ & $\begin{array}{c}\text { Waktu } \\
\text { Retensi } \\
\text { (menit) }\end{array}$ & $\begin{array}{c}\text { Luas Area } \\
\left(\mathbf{m A U} \mathbf{H}^{*}\right)\end{array}$ \\
\hline 5,0 & 1,184 & 32,23305 \\
10,0 & 1,008 & 65,02857 \\
15,0 & 1,008 & 97,40105 \\
20,0 & 1,004 & 129,75168 \\
25,0 & 1,001 & 178,27931 \\
30,0 & 0,993 & 210,57770 \\
\hline
\end{tabular}

Berdasarkan data pada Tabel 3 dapat dilihat bahwa luas area puncak kromatogram larutan standar klorpirifos semakin besar jika volume injeksi sampel diperbesar, namun pada volume injeksi $\geq 20 \mu \mathrm{L}$, kromatogram larutan baku klorpirifos menjadi tidak simetri lagi. Oleh karena itu, dalam penelitian ini digunakan volume injeksi sampel $15 \mu \mathrm{L}$, karena menghasilkan kromatogram yang lebih baik seperti diperlihatkan dalam Gambar 5.

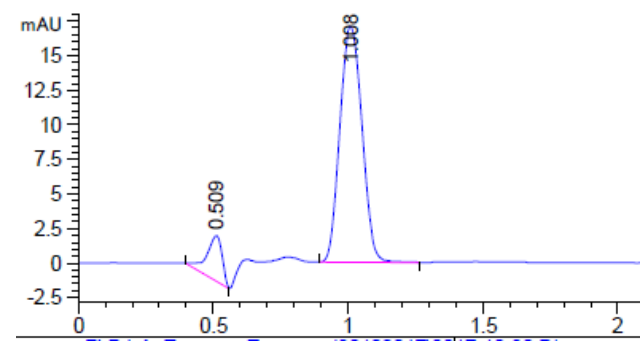

Gambar 5. Kromatogram klorpirifos pada volume injeksi sampel $15 \mu \mathrm{L}$

Berdasarkan hasil otimasi parameterparameter kromatografik di atas, maka dapat diringkaskan kondisi optimum HPLC untuk penetapan residu klorpirifos seperti ditunjukkan dalam Tabel 4 berikut. 
Tabel 4. Kondisi optimum HPLC untuk penentuan klorpirifos

\begin{tabular}{|c|c|c|}
\hline $\begin{array}{c}\text { Volume } \\
\text { Injeksi } \\
\text { Sampel }(\mu \mathrm{L})\end{array}$ & $\begin{array}{l}\text { Waktu } \\
\text { Retensi } \\
\text { (menit) }\end{array}$ & $\begin{array}{c}\text { Luas Area } \\
\left(\mathrm{mAU} \mathrm{U}^{*} \mathrm{~s}\right)\end{array}$ \\
\hline 5,0 & 1,184 & 32,23305 \\
\hline 10,0 & 1,008 & 65,02857 \\
\hline 15,0 & 1,008 & 97,40105 \\
\hline 20,0 & 1,004 & 129,75168 \\
\hline 25,0 & 1,001 & 178,27931 \\
\hline 30,0 & 0,993 & 210,57770 \\
\hline
\end{tabular}

\section{Penentuan Kinerja Analitik}

a. Presisi

Presisi merupakan ukuran yang menunjukkan derajat kesesuaian antara hasil uji individual, diukur melalui penyebaran hasil individual dari rata-rata jika prosedur diterapkan secara berulang pada sampel-sampel yang diambil dari campuran yang homogen [6]. Pada penelitian ini, presisi ditetapkan berdasarkan keterulangan luas area kromatogram hasil analisa dengan 7 kali pengulangan pada larutan standar. Kriteria presisi diberikan jika metode memberikan simpangan baku relatif (RSD) atau koefisien variasi (CV) $2 \%$ atau kurang [6]. Hasil pengukuran ditunjukkan dalam Tabel 4 .

Tabel 5. Penentuan Keterulangan

\begin{tabular}{|c|c|}
\hline Pengukuran ke- & Luas Area \\
\hline 1 & 138,33823 \\
\hline 2 & 139,04747 \\
\hline 3 & 138,96838 \\
\hline 4 & 138,69792 \\
\hline 5 & 139,07574 \\
\hline 6 & 139,10226 \\
\hline 7 & 138,62209 \\
\hline Rerata & 138,83601 \\
\hline Simpangan Baku (SB) & 0,28960094 \\
\hline Koefisien Variasi (KV) & $0,20859209 \%$ \\
\hline
\end{tabular}

Berdasarkan hasil penenlitian seperti yang ditunjukkan dalam Tabel 5, dapat dilihat bahwa nilai koefisien variasi $(\mathrm{KV})$ untuk penentuan klorpirifos 2 ppm adalah 0,2086\%. Karena nilai KV lebih kecil dari $2 \%$ maka metode analisis tersebut mempunyai presisi yang baik [6]. Dengan demikian dapat disimpulkan bahwa sistem operasional alat dan analisis memiliki nilai keterulangan yang baik terhadap metode dengan respon yang relatif konstan, sehingga hasil pengukuran memiliki nilai presisi yang memenuhi persyaratan.

\section{b. Linearitas dan Kurva Kalibrasi}

Linearitas adalah kemampuan metode analisis memberikan respon proporsional terhadap konsentrasi analit dalam sampel [7]. Linearitas biasanya dinyatakan dalam istilah variansi sekitar arah garis regresi yang dihitung berdasarkan persamaan matematik data yang diperoleh dari hasil uji analit dalam sampel dengan berbagai konsentrasi analit [6]. Sebagai parameter adanya hubungan linier digunakan koefisien korelasi $r$ pada analisis regresi linier $y=a+b x$. Hubungan linier ideal dicapai jika nilai $a=0$ dan $r=+1$ atau -1 , bergantung pada arah garis [7].

Berdasarkan hasil pengkuran 5 seri larutan satndar klorpirifos dengan rentang konsentrasi 2 - 10 ppm, didapatkan kurva kalibrasi dengan persamaan garis regresi $y=27,6 x+23,391$ dan nilai koefisien korelasi $R^{2}=0,9963$ seperti ditunjukkan dalam Gambar 6.

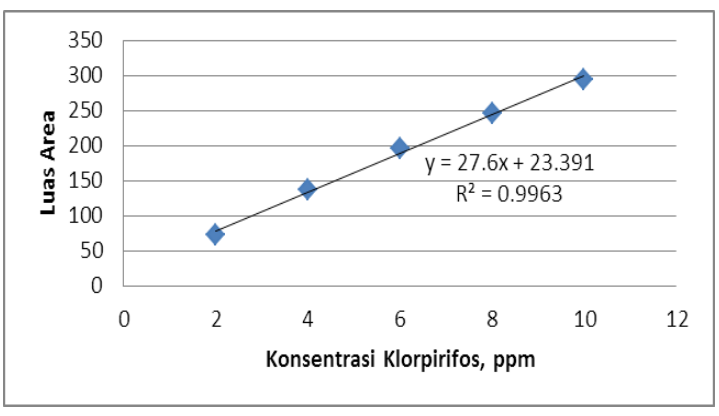

\section{Gambar 6. Kurva kalibrasi Larutan Standar} Klorpirifos

Nilai regresi yang baik adalah $\mathrm{R}^{2}>0,99$ [4, 8]. Dengan demikian, nilai koefisien korelasi yang diperoleh telah memenuhi persyaratan untuk digunakan dalam pengukuran analisis rutin.

\section{c. Batas Deteksi dan Batas Kuantitasi}

Batas deteksi (LOD) adalah jumlah terkecil analit dalam sampel yang dapat dideteksi yang masih memberikan respon signifikan dibandingkan dengan blangko, sedangkan batas 
kuantitasi (LOQ) merupakan parameter pada analisis renik dan diartikan sebagai kuantitas terkecil analit dalam sampel yang masih dapat memenuhi kriteria cermat dan seksama [7]. Nilai LOD dan LOQ dihitung secara statistik melalui garis regresi dari kurva kalibrasi.

Berdasarkan hasil penelitian yang dilakukan untuk penentuan klorpirifos dengan metode HPLC, diperoleh nilai LOD sebesar 0,67 ppm dan nilai LOQ sebesar 2,24 ppm. Batas deteksi berguna dalam memastikan suatu respon yang ditimbulkan suatu analisis [9].

\section{Ucapan Terimakasih}

Terima kasih disampaikan kepada Direktorat Riset dan Pengabdian kepada Masyarakat (DRPM) Kementrian Riset, Teknologi dan Pendidikan Tinggi, yang telah mendanai penelitian ini melalui skema Penelitian Dosen Pemula (PDP),

\section{Kesimpulan}

Berdasarkan hasil penelitian yang telah diperoleh, maka dapat ditarik kesimpulan sebagai berikut:

1) Penentuan konsentrasi klorpirios dalam sayur kubis dapat dilakukan dengan metode HPLC menggunakan kolom Zorbax Eclipse Plus C18 pada kondisi optimum yang diperoleh, yaitu $\lambda=289 \mathrm{~nm}$, komposisi fasa gerak (air: asetonitril) $=(10: 90)$, laju alir fasa gerak $=0,70 \mathrm{~mL} / \mathrm{menit}$, dan volume injeksi sampel $=15 \mu \mathrm{L}$.

2) Kinerja analitik penentuan klorpirifos dengan metode HPLC tergolong sangat baik, hal ini ditunjukkan dengan parameter pengukuran seperti: presisi ditunjukkan dengan koefisien variasi $(\mathrm{KV})=0,2086 \%$, linearitas ditunjukkan dengan koefisien korelasi $(r)=0,9963$, batas deteksi $(L O D)=$ 0,67 ppm, dan batas kuantitasi (LOQ) $=2,24$ ppm, yang semuanya memenuhi persyaratan.

\section{Daftar Pustaka}

1. Chen, C.; Qian, Y.; Chen, Q.; Tao, C.; Li, C.; $\mathrm{Li}, \mathrm{Y}$., Evaluation of pesticide residues in fruits and vegetables from Xiamen, China. Food Control 2011, 22, (7), 1114-1120.

2. Yao, Z.-w.; Jiang, G.-b.; Liu, J.-m.; Cheng, W., Application of solid-phase microextraction for the determination of organophosphorous pesticides in aqueous samples by gas chromatography with flame photometric detector. Talanta 2001, 55, (4), 807-814.

3. Sastroutomo, S. S., Pestisida Dasar-Dasar dan Dampak Penggunaannya. PT Gramedia Pustaka Utama. Jakarta. Hlm 1992.

4. Panggabean, A. S.; Amran, M. B.; Achmad, S., Speciation of organotin compounds with ion pair-reversed phase chromatography technique. Eurasian Journal of Analytical Chemistry 2009, 4, (2), 215-225.

5. Panggabean, A. S., Analisis residu klorpirifos dalam sayur-sayuran dengan teknik high performance liquid chromatography (HPLC). Jurnal Kimia Mulawarman 2016, 13, (2).

6. Harmita, H., Petunjuk pelaksanaan validasi metode dan Cara Perhitungannya. Pharmaceutical Sciences and Research (PSR) 2012, 1, (3), 117-135.

7. Riyanto, Validasi \& Verifikasi Metode Uji: Sesuai dengan ISO/IEC 17025 Laboratorium Pengujian dan Kalibrasi. Deepublish: Yogyakarta, 2014.

8. Mulja, J.; Miller, J., Statistika Untuk Kimia Analitik Edisi kedua. Terjemahan Suroso. Bandung: Penerbit ITB: 1991.

9. Panggabean, A. S.; Pasaribu, S. P.; Bohari, B.; Nurhasanah, N., Preconcentration of Chromium (VI) at Trace Levels Using Acid Alumina Resin with Column Method. Indonesian Journal of Chemistry 2014, 14, (1), 51-56. 